\title{
Attendance of Students in Government Elementary Schools: A Study on Jharkhand
}

DOI: https://doi.org/10.47175/rielsj.v2i2.254

\author{
| Ramakanta Mohalik ${ }^{1, *}$ \\ ${ }^{1}$ Regional Institute of \\ Education (RIE), \\ Bhubaneswar, India \\ ${ }^{2}$ Associate Professor, RIE \\ Bhubaneswar, India \\ 3JPF, RIE Bhubaneswar, India \\ *mohalikrk@gmail.com.
}

\section{Rasmirekha Sethy ${ }^{2}$ | Ms. Sangeeta ${ }^{3}$ |}

\section{INTRODUCTION}

Elementary education is the stepping-stone towards secondary and higher education. It lays the foundation of study on which the pillars of career stands. It prepares the students to pursue their learning with confidence. But continuation of learning is possible only when students come to school regularly. If they will not come to school regularly then they will miss the important concept taught by the teacher. Low attendance causes many problems in proper running of the school and it ruins the life of students. In fact, attendance is the key for a child to be successful in their school career. Vital things are missed if the child is absent even just one day. The Government of India has implemented many initiatives such as Mid Day Meal, Sarva Sikhsha Abhiyan (SSA), Right to Education, Samagra Shiksha, NISHTHA etc. for the improvement of elementary education in general and rate of attendance in particular. Similarly, the Government of Jharkhand has implemented many plans and policies like Vidyalaya Chalen Abhiyan, Prayas, Khel Mein, Buniyad, Bal Samagam, Bal Sansad and Pahle Padhai Phir Vidai etc. for promotion of elementary education. In-spite of all these initiatives, all students in Government schools are not attending school regularly. 


\section{Rationale of the Study}

Attendance is the key for a child to be successful in their school career. Irregular students devastate their success in school. School absenteeism is an alarming problem for administrators, teachers, parents, society in general and pupils in particular. Attending school is very important and essential for the overall development of the child i.e., social, emotional, physical, academic and personal. When a student is absent from class, it has an adverse effect on their academic performance also. This is because frequent absence may lead to missing important information, facts and instructions that result in partial understanding of a topic, submission of incomplete work and poor participation in class activities (Vidyakala and Priya, 2017). On the individual level, health problems, truancy and personal interest are some of the factors leading to irregular attendance among students. Thapa and Sarkar (2019) found that due to livelihood pressure at home and the double burden of household chores and income-generating work along with inadequate support from school made it challenging for children to complete elementary education. The similar findings reported by Sahin and Arseven (2016) and Shahzada, et.al. (2011) that children of seasonal worker families are kept away from school for a long time and this has a considerably negative effect on the children's school lives. Further, Sekiwu et al. (2020) found that there is a positive linkage between school attendance and academic preperformance. This is supported by Khalid and Mehmood (2017) who reported that $61 \%$ of teachers are strongly agree that absenteeism has a significant effect on students' class participation. Apart from these, Amalu and Abang (2016) stated that financial constraints, lack of interest, illnesses, pampering from family members, location of school were the major causes of absenteeism among pupils. Similar findings are reported by Ghosh et al. (2017) that the chief reasons for irregularity of students were illness (18.98\%), rainy days $(16.45 \%)$, and social or family occasions (11.28\%). Senyametor et al. (2018) reflected that 71.4 percent of absenteeism was due to teachers' inability to care the pupils, while 70 percent of teachers indicated lack of parental care was the major cause of absenteeism of students. It is contradicted by Vidyakala and Priya (2017) that home location of the students has negative relationship with student absenteeism. Karlberg et al. (2020) and Aseefa (2018) indicated that positive school climate was associated with less unauthorized absenteeism.

Student absenteeism from school impacts not only students' educational progress but also affects their social and personal development. Many causes such as home, parents, school facilities, teaching learning resources, school environment \& style of teaching etc. are responsible for low attendance of students in schools. However, the investigator has not found any comprehensive study on causes of low attendance of students at elementary level in Jharkhand. Hence it is pertinent to study low attendance of students at elementary level.

\section{Objectives}

The objectives of this study is to explore the causes of low attendance of students in Government elementary schools in perspective of teachers and Head Teacher (HT).

\section{RESEARCH METHODS}

The investigator used quantitative research approach and survey method to study the different causes which are responsible for low attendance of students in Government elementary schools from the perspectives of teachers and HTs. The sample selected for the study were 78 teachers and 30 HTs. The purposive sampling method was thought to be the best method during Pandemic. So, 78 teachers and 30 HTs were purposefully selected from 
the two districts of Jharkhand, India i.e., Dhanbad and Lohardaga. Self-developed checklist for teachers and head teachers was used as tool for collecting data. The items were based on factors relating to home, school, student and teacher to know the reasons of low attendance of students at elementary level and it is measured by two-point scales i.e. Yes and No. Data were collected online by google form. The frequency and percentage were used for data analysis and presentation. On the basis of data analysis, the Investigator has made interpretations about the causes of low attendance of students in schools.

\section{RESULTS AND DISCUSSION}

The objective of the study is to explore the causes of low attendance of students in elementary schools. The responses of teachers and HTs are presented in following tables.

Table 1. Home Related Causes

\begin{tabular}{cll}
\hline $\begin{array}{c}\text { Sl. } \\
\text { No. }\end{array}$ & Items & $\begin{array}{l}\text { Yes } \\
(\mathbf{N ~ \& ~ \% )}\end{array}$ \\
\hline 1 & Students go to work for earning money for the family. & $84^{*}(77.77)^{* *}$ \\
2 & Both parents are working. & $74(68.52)$ \\
3 & Abusive home environment. & $74(68.52)$ \\
4 & Migration of parents for job & $74(68.52)$ \\
5 & Children take care of siblings during school hours. & $66(61.11)$ \\
6 & Illness of family members. & $64(59.26)$ \\
7 & Homesickness of children. & $64(59.26)$ \\
8 & Dropout of siblings and friends. & $62(54.41)$ \\
9 & Parents do not encourage students to attend school. & $52(48.15)$ \\
10 & Involvement students in domestic work. & $52(48.15)$ \\
11 & Girls help mother in household work. & $48(44.44)$ \\
12 & Early marriage of girls. & $40(37.04)$ \\
13 & Due to peer influence. & $20(18.52)$ \\
\hline
\end{tabular}

*Frequency, **Percentage

The table 1 indicated that $77.77 \%$ of respondents viewed causes of low attendance is students go for work to earn money for the family. Further, $68.52 \%$ of respondents viewed that both parents are working, abusive home environment and migration of parents for searching jobs are causes of low attendance. $61.11 \%$ of children do not attend school regularly as they take care siblings. $59.26 \%$ of respondents expressed that students do not attend school due to illness of family member and homesickness. Further, less than $50 \%$ of respondents are of the opinion that students do not attend school as parents do not encourage them to attend school and students are involved in the domestic work. The major home related causes of low attendance is graphically presented in figure 1 . 


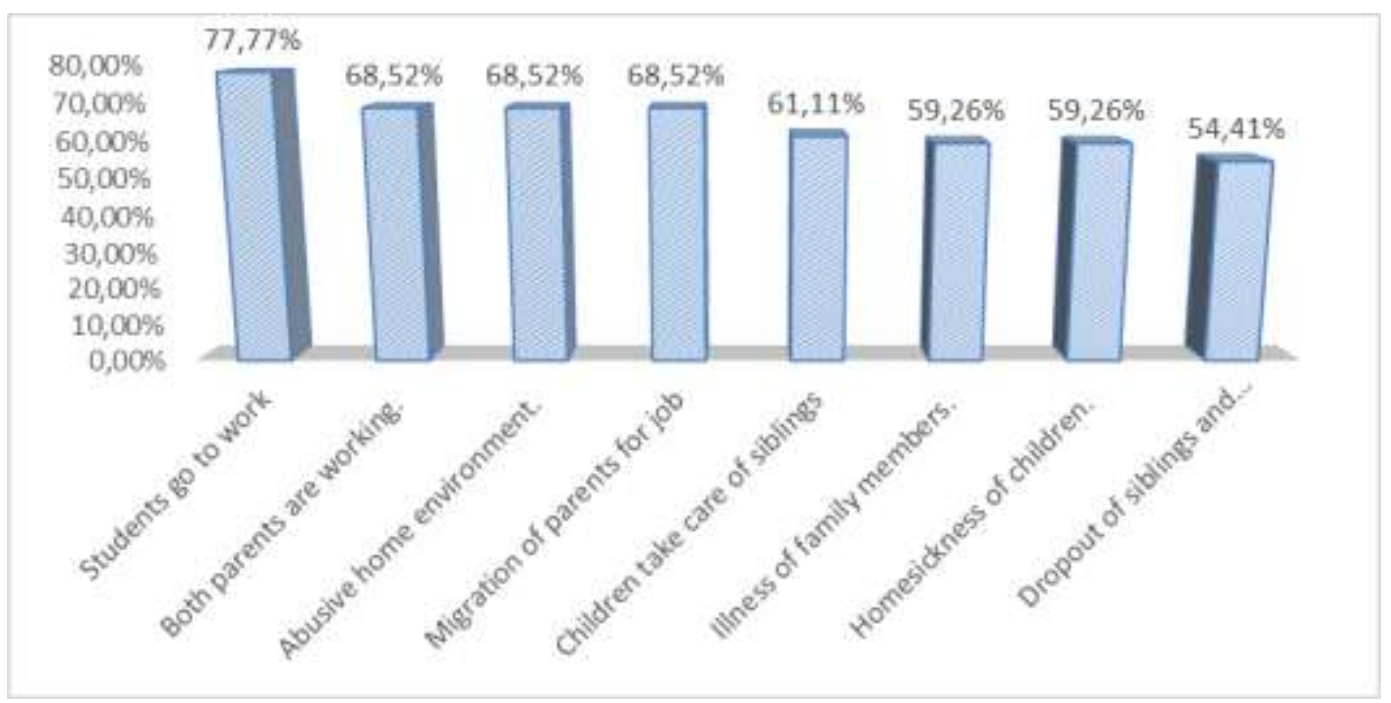

Figure 1. Major home related causes of low attendance

Table 2. School Related Causes

\begin{tabular}{lll}
\hline $\begin{array}{l}\text { Sl. } \\
\text { No. }\end{array}$ & Items & $\begin{array}{l}\text { Yes } \\
(\mathbf{N ~ \& ~ \% ) ~}\end{array}$ \\
\hline 1 & Due to long vacation & $78(72.22)$ \\
2 & Less involvement of SMC members. & $50(46.30)$ \\
3 & Facilities of school do not attract students. & $40(37.04)$ \\
4 & Lack of toilet and hygiene facilities for girls. & $34(31.48)$ \\
5 & Non- detention policy. & $30(27.78)$ \\
6 & Disturbance around the school campus. & $28(25.92)$ \\
7 & Lack of women teacher. & $28(25.92)$ \\
8 & Poor connecting road to school & $24(22.22)$ \\
9 & Poor parent teacher relationship. & $22(20.37)$ \\
10 & School is distance from home & $16(14.81)$ \\
11 & Lack of monitoring of attendance by higher authority. & $12(11.11)$ \\
\hline
\end{tabular}

It is revealed from the table 2 that $72.22 \%$ of respondents expressed that long school vacations are the cause of low attendance. Further, due to less involvement of SMC in enrollment and attendance of students is the cause of low attendance. The table also indicates that facilities of school do not attract students to come to school regularly. $31.48 \%$ of respondents are of the opinion that lack of toilet and hygiene facilities causes low attendance among girls. Further, less than $30 \%$ of respondents expressed that students do not attend school because of non-detention policy and poor parent teacher relationship. $25.92 \%$ of respondents viewed that disturbance around the school campus creates dislike among students to come to school and lack of women teacher is the cause of low attendance. Around $20 \%$ of respondents said that students are not coming due to poor connecting road to school and less than $15 \%$ respondents expressed that students do not come to school as school is distance from home. Again, it is reflected by $11.11 \%$ of respondents that lack of monitoring by higher authority is the cause of low attendance. The main causes of low attendance related to school is presented graphically in figure 2 . 


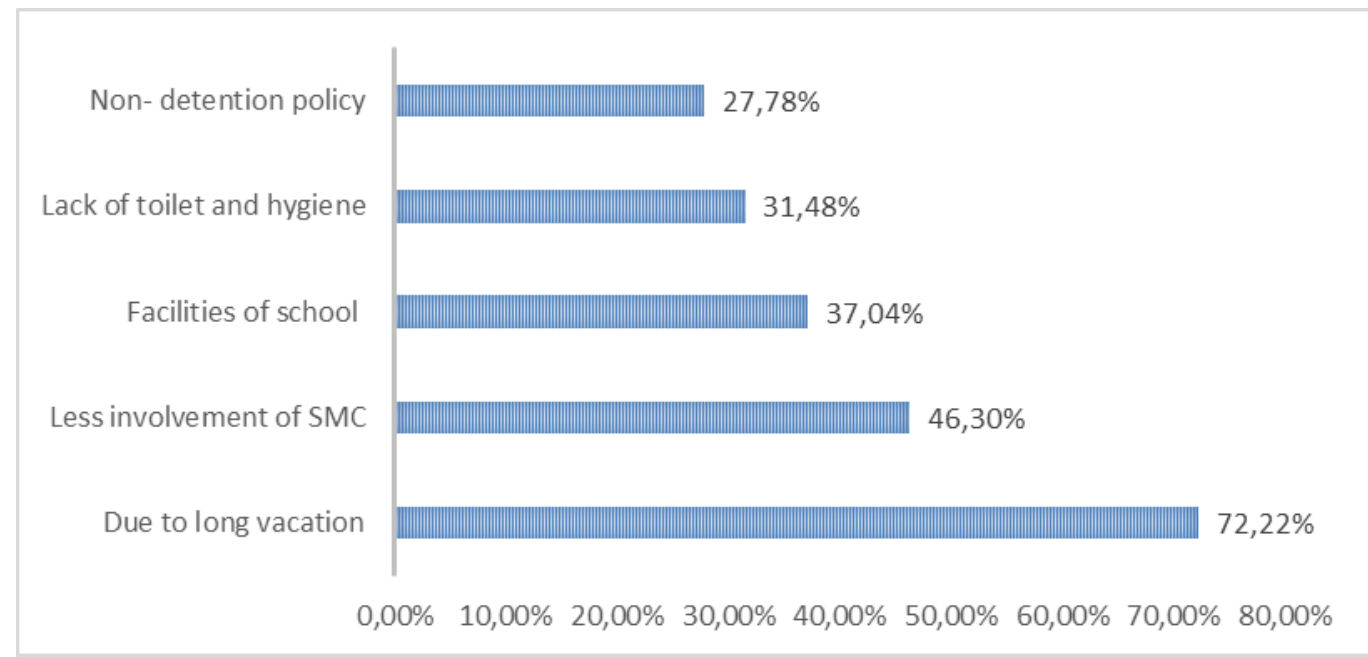

Figure 2. Main School Related Causes of Low Attendance

Table 3. Teacher Related Causes

\begin{tabular}{cll}
\hline $\begin{array}{c}\text { Sl. } \\
\text { No. }\end{array}$ & Items & $\begin{array}{l}\text { Yes } \\
\text { (N \& \%) }\end{array}$ \\
\hline 1 & Vacant teachers position in school. & $52(48.15)$ \\
2 & Teacher does not communicate in the language of the child. & $34(31.48)$ \\
3 & Teacher does not motivate students to attend school. & $30(27.78)$ \\
4 & Teacher does not make teaching enjoyable. & $30(27.78)$ \\
5 & Teachers are unable to transact the curriculum properly. & $26(24.07)$ \\
6 & Teachers use traditional method. & $20(18.52)$ \\
7 & Partial treatment of teacher. & $18(16.67)$ \\
8 & Teachers are not taking classes regularly. & $12(11.11)$ \\
9 & Students could not understand the lesson taught by the teacher. & $10(9.26)$ \\
10 & Teachers do not take the class regularly. & $8(7.41)$ \\
\hline
\end{tabular}

It is found from the table 3 that $48.15 \%$ of respondents identified that students do not come due to lack of teachers. Teachers does not communicate in the language of the child is one of the cause of low attendance expressed by $31.48 \%$ of respondents. Less than $30 \%$ of respondents identified that ineffective, non-enjoyable and inappropriate method of transacting of curriculum is the cause of low attendance of students. $29.63 \%$ respondents viewed that students do not come to school as they are not interested in learning. Further, less than $20 \%$ of respondents explained that traditional method and irregular mode of teaching de-motivate students to attend school regularly. It also reveals that less than $20 \%$ of respondents reflected that students do not attend school due to partial treatment of respondents. Few percentage of students do not come to school as they could not understand the lesson taught by the teacher.

Table 4. Student Related Causes

\begin{tabular}{cll}
\hline $\begin{array}{c}\text { Sl. } \\
\text { No. }\end{array}$ & Items & $\begin{array}{l}\text { Yes } \\
(\mathbf{N ~ \& ~ \% ) ~}\end{array}$ \\
\hline 1 & During harvesting session. & $86(79.63)$ \\
2 & During rainy days & $84(77.78)$ \\
3 & Students are weak in studies. & $44(40.74)$ \\
4 & Lack of basic reading and writing skills. & $42(38.89)$ \\
5 & Inferiority complex of students. & $34(31.48)$ \\
6 & Students are not interested in learning. & $32(29.63)$ \\
\hline
\end{tabular}




\begin{tabular}{lll}
\hline 7 & Non-completion of homework. & $30(27.77)$ \\
8 & Poor performance in previous class. & $28(25.93)$ \\
9 & Strict behavior of teacher. & $26(24.07)$ \\
10 & Physical disability of students. & $22(20.37)$ \\
11 & Poor relation with peers. & $20(18.52)$ \\
12 & Over age of students/children. & $14(12.96)$ \\
13 & Fear of teachers. & $6(5.56)$ \\
14 & Fear of punishment of teachers. & $6(5.56)$ \\
\hline
\end{tabular}

The table 4 pointed out that more than $70 \%$ of respondents viewed that students do not come to school during harvesting session and rainy season. $41 \%$ of respondents viewed that students do not come to school as they are weak in studies. Less than $40 \%$ of respondents expressed that students miss the school because they lack basic reading and writing skills and have inferiority complex. Again, less than $30 \%$ of respondents identified that low attendance is due to poor performance in previous class and physical disability of students. The table further indicated that around $25 \%$ of respondents reported students do not attend school due to non-completion of homework and strict behavior of teachers. Further, less than $20 \%$ of respondents expressed that students do not come to school due to poor relation with peers and over age. The major causes related to students is graphically presented in figure 3.

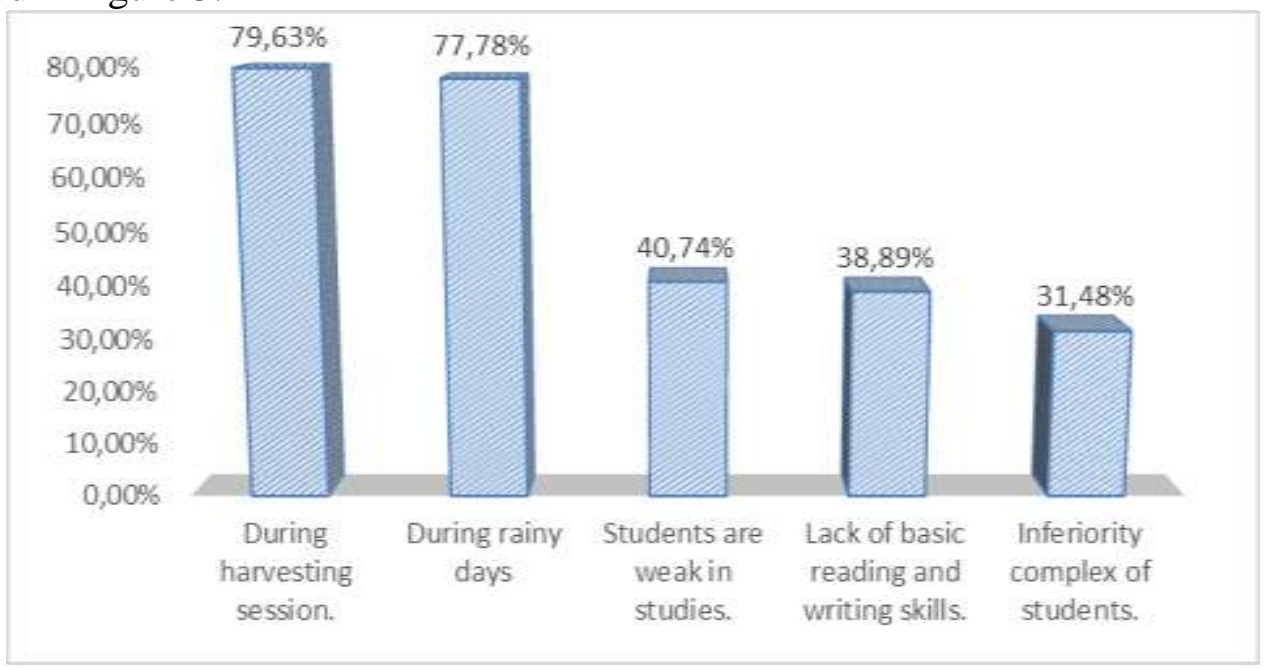

Figure 3. Major Student Related Causes of Low Attendance

\section{Major Findings}

- Students studying in elementary school go to work to earn money for the family is one of the causes of low attendance. Nobody in the family to send children to school as both parents go for work as expressed by more than $68 \%$ of respondents.

- Children are involved in domestic work/ help parents in work, take care of siblings etc. for which they miss the school. Further, parents do not encourage children for going to school regularly may be the cause of low attendance.

- Majority of parents migrate from one place to another place for searching job so children also migrate along with parents for which children could not attend school regularly.

- Abusive home environment of children does not encourage and monitor children to attend school regularly. Further, homesickness of children may be one of the factors of low attendance. 
- Due to lack of teachers in school, students are not meaningfully engaged in learning for which students do not come to school. $46 \%$ of the SMC does not help school in brining all children to school regularly.

- More than 30 percent of respondents believed that students are not coming to school due to less interest in studies, poor in studies, lack in basic reading and writing skills and have inferiority complex.

- More than $70 \%$ of respondents responded that students do not attend school during harvesting season, rainy season and after long vacations.

\section{Discussion}

The investigator intended to find out the causes of low attendance of students in Government elementary schools of Jharkhand. It is found that both the parents are working due to poor financial condition and majority of students are also working to contribute income to their family. This is supported by Thapa and Sarkar (2019), Amalu and Abang (2016) and Shahzada et al. (2011). Further, low attendance affects the regular attendance of students as both the parents are working and nobody is there to send their children to school. Due to lack of parental care, students are not attending school which is agreed by Senyametor et al. (2018). Migration of parents in search of job affects the regular schooling of students as they also move with their parents. Sahin and Arseven (2016) reported that seasonal workers move from one place to another in search of job which ultimately creates disinterest for schooling among children. The study found that the majority of students do not attend school during harvesting season, rainy season and after long vacations. This result is supported by Ghosh et al. (2017), Sahin and Arseven (2016). It is also found that majority of students do not attend school because they are less interested in studies as multi-grade classes do not satisfy their understanding of the subject. One room for each class is not available in majority of schools. Teachers are the nation builders but they are unable to serve their actual duty and involved in other work apart from teaching. Toilet facility is one of the basic infrastructural facilities in school but still many schools do not have this facility which discourages students for not attending regular schools. In some school availability of lady teacher is one of the major concerns because of this majority of girls students are not attending school as with whom they will share their problems and parents were afraid of their safety.

\section{Educational Emplications}

- This study indicated that causes related to family and parents such as working of both parents, involvement of children in domestic work, taking care of siblings, migration of parents for work, during farming and harvesting session, low aspiration of parents etc. are responsible for low attendance of students in elementary school. Students can only regularly attend school when parents take interest and monitor students attendance. Parent must motivate and encourage their wards for attending school as well as free student from domestic work during school hours. It is required to create awareness for parents about importance of education in the life of children and how education can improve the quality of life. The Government departments as well as civil society, NGOs, local PRI members, SMC members, volunteers may take up this awareness programme for parents. The Government must use non formal education channels to educate parent in basic literacy and numeracy which can motivate parents to send their wards to school regularly.

- Student related factors such as low motivation for study, poor in academic, lack of basic reading, writing skills, peer pressure, early marriage of girls etc. are identified as 
another important aspect of low attendance. Both parents and respondents can work hand in hand to create motivation for education and develop basic literacy skills which are necessary for success in formal education. School can provide counselling service to all demotivated students to up their motivation for studies. Respondents can plan and provide extra classes in suitable time for providing basic literacy skills so that student can understand what is taught in school.

- School related factors such as inadequate infrastructure, teaching learning resources, textbooks, lack of respondents, poor teaching strategy, multigrade teaching, lack of regular head teacher, participation of SMC etc. are leading to low attendance of students. Hence, basic infrastructure facilities like classrooms equipped with electricity, fans, blackboard etc. must be provided which help school to provide better school environment. Conducive school environment can motivate and attract children to school regularly.

- Teaching learning resources like science kits, mathematic kits, globes, charts etc. are essential to provide meaningful learning experience to student. In scientific learning, students are trained to be able to carry out higher order thinking processes (Ardhyantama and Widodo, 2020). It is found that majority of schools lack these resources. It is suggested to the Government for taking initiatives to provide minimum teaching learning resources to all elementary schools so that children can learn effectively which can help school to attract students.

- Teacher is the backbone of school education system. It is not possible to increase attendance in schools without support and cooperation of teachers. All teachers may be provided training in child cantered, art integrated and sports integrated pedagogy so that they can make classroom teaching livelier and more effective. This will motivate students to come to school regularly.

- The problem of low attendance in Government schools need to be properly monitored and managed by the help of HMs, SMC, and PRI members. The Government may take urgent initiative to appoint regular HTs in all elementary schools who can take major academic decision for school development. Further, all SMC and PRI members may be oriented and encouraged to cooperate in the school development and brining all children of their locality to school regularly.

\section{CONCLUSION}

Education forms the foundation of any society. The growth and development of society depends upon the quality of education imparted in schools. So, school plays an important role in moulding a nation's future by facilitating all round development of its future citizen. The attendance rate is important because students are more likely to succeed in academics when they attend school consistently. It is difficult for the teacher and the class to build their skills and progress if many students are frequently absent. The Government has been trying to provide basic facilities in elementary schools but still the students are not approachable because there are some problems which are beyond the curtain and it is not visible through naked eyes. The Government should take initiate to remove the barriers which are related to student's personal life like family problems, siblings' issues, teacher absent etc. Finally, it can be said that these problems are not new, but with the passage of time, we are not able to eradicate it completely. The rate of attendance will not improve until and unless barriers are removed from the path of education. It can only be achieved by the cooperation of parents, teacher, civil society, and education officers. Once regular attendance is ensured, then we can provide quality education to all children. 


\section{REFERENCES}

Amal, M.N. and Abang, K.B. (2016). School Absenteeism among Primary School Pupils in Cross River State: Psychological Implication for National Development. Global Journal of Educational Research, 15, 49-56.

Ardhyantama, V., \& Widodo, S. (2020). Creativity Skill Proses in Project Based Learning: A Case Study of Distance Learning in Pacitan. Randwick International of Education and Linguistics Science Journal, 1(2), 152-158.

Aseefa, M. (2018). Cause and Possible Solution to the Problem of Absenteeism on Students' Academic Achievement: The case of Secondary Schools Addis Ababa., Ethiopia. International Journal of Advanced Multidisciplinary Research, 5 (12), 8-19.

Ghosh, A., Dasgupta, A., Karmakar, S. R., Bandyopadhyay, L., Sembiah, S., and Biswas, B. (2017). Assessment of School Absenteeism: A Community-Based Study among Children Aged 7-18 Years in a Slum of Kolkata. International Journal of Medical Science and Public Health, 7 (2), 97-102.

Karlberg, M. Klang, N., Andersson, F., Hancock, K., and Wreder, L. F., Kearney, C. and Galanti, M. R. (2020): The Importance of School Pedagogical and Social Climate to Students' Unauthorized Absenteeism - a Multilevel Study of 101 Swedish Schools. Scandinavian Journal of Educational Research, 65(3), 1-17.

Khalid, N and Mehmood, K. (2017). Effects of Absenteeism on Students Performance. International Journal of Scientific and Research Publications, 7 (9), 151-168.

Sahin, S. and Arseven, Z. (2016). Causes of Student Absenteeism and School Dropouts. International Journal of Instruction, 9 (1), 195-210.

Senyametor, F., Gyimah, E. F., and Vincent Mensah Minadzi. (2018). Factors Affecting Pupils' Absenteeism at Felicormfort Junior High School (JHS) in Cape Coast, Ghana. Journal of Education and Learning, 7 (6), 138-149.

Sekiwu, D., Ssempala, F., and Frances, N. (2020). Investigating the Relationship between School Attendance and Academic Performance in Universal Primary Education: The Case of Uganda. African Educational Research Journal, 8 (2), 152-160.

Shahzada, G., Ghazi, S. R., Nawaz, H. and Khan, A. (2011). Causes of Absenteeism from the Schools at Secondary Level. Mediterranean Journal of Social Sciences, 2 (2), 291298.

Thapa, R., and Sarkar, K. K. (2019). Universal Elementary Education in India: Barriers and Persistent Challenges, Social Change, 49 (2), 257-275.

Vidyakala, K. and Priya, M. V. (2017). Factors Influencing Student Absenteeism in School. International Journal of Science and Research, 6 (6), 2762-2764. 